\title{
Breast Fibrocystic Change, Proliferative Type
}

National Cancer Institute

\section{Source}

National Cancer Institute. Breast Fibrocystic Change, Proliferative Type. NCI Thesaurus.

Code C6940.

Breast fibrocystic change characterized by the presence of epithelial cell hyperplasia.

Epithelial atypia may be present or absent. 